\title{
Effect of Drip Irrigation and Phosphorus Fertilization on the Growth of Peanut Plants Grown on Sandy Calcareous Soils
}

\author{
M. Hefzy", H.G. Hassanein ${ }^{* *}$, M.A. Gameh ${ }^{* *}$ and M. M. A. \\ El-Koliey" \\ ${ }^{*}$ Water Req. and Field Irrig. Res. Dept., SWERI, Agricultural \\ Research Centre and ${ }^{* *}$ Soils and Water Dept., Faculty of \\ Agriculture, Assuit University, Egypt.
}

\begin{abstract}
7 IELD experiments were carried out at the Experimental Farm of Arab El- Awammer Research Station, Agriculture Research Center, Assuit, Egypt, during the two successive growth summer seasons of 2010 and 2011, to study the effect of two levels of phosphorus fertigation ( 23 and $31 \mathrm{~kg} \mathrm{P}_{2} \mathrm{O}_{5} /$ fed) divided into different doses (3, 6 and 9 doses) under different irrigation regimes (80 and $100 \%$ from pan evaporation). Water consumptive use, irrigation water use efficiency (IWUE), peanut yield and yield components were evaluated. The obtained results could be summarized as follows:

The seasonal average quantity of irrigation water applied to peanut plants was 754.8 and $943.5 \mathrm{~mm}$ which equals 80 and $100 \%$ of pan evaporation, respectively. The crop evapotranspiration of peanut was 858.8 and $783.6 \mathrm{~mm}$ in the first and second seasons, respectively, as calculated by Penman Monteith equations.

Peanut yield and yield traits were significantly increased with increasing the levels and doses of phosphorus fertilization. The highest values of WUE and IWUE were obtained from the highest level of phosphorus fertilization under irrigation with $80 \%$ of pan evaporation.
\end{abstract}

Keywords: Peanut, Fertigation, Drip irrigation, Sandy calcareous soil, Phosphorus fertilization.

The demands on agricultural products and water resources were increased steeply every where at the same time. Water is a limiting factor in any agricultural expansion depending on its quantity, quality and methods of water application. Growing of a fallow crop as peanut could be a good choice because of its high economic value and the benefit of legumes in the maintenance of soil organic $\mathrm{N}$. Peanut is grown in many arid and semiarid regions during dry seasons therefore; it needs to be irrigated to produce economic yields. The application of fertilizers through the irrigation system (fertigation) became a common practice in modern agriculture. Increased yields, improvement in quality of the product, water and nutrient expense efficiencies and protection of the environment are some of the main characteristics of this method. 
Doorenbos et al. (1979) reported that, water requirements for peanut depending on climate, range from 2100 to $2940 \mathrm{~m}^{3} /$ fed. for growth season. Tayel and Wahba (1989) found that the peanut was planted in a sandy soil, irrigated by center pivot irrigation system in El-Sharkia governorate, the recorded maximum seasonal evapotranspiration (ETm) and the actual one (ETa) were 3326.4 and $2389.8 \mathrm{~m}^{3}$ / fed., respectively. Water deficit, occurred especially during flowering and the early part of yield formation periods led to $21 \%$ reduction in yield. Using the $2389.8 \mathrm{~m}^{3} /$ fed and avoiding the deficits during flowering and early part of yield formation stages increased the yield. El-Koliey et al. (2001) estimated the seasonal water requirements for peanut crop grown under surface, sprinkler and drip irrigation systems in Assuit region, were 5622, 3748 and 3307, $\mathrm{m}^{3} /$ fed., respectively. Mohamed and Usman (2007) found that the seasonal actual applied amounts of irrigation water were 980, 1960, 2940 and $3920 \mathrm{~m}^{3} /$ fed. while, the seasonal measured depleted water was $960.83,1718.92$, 2113.10 and $2414.88 \mathrm{~m}^{3}$ /fed. when irrigated with $15,30,45$ and 60 min every 2 days, respectively. El-Boraie et al. (2009) found that the maximum water depletion values were found at the develop and mid stages of plant growth. The superior effect on pod yield (1824 kg/fed.) was obtained with applying $983.73 \mathrm{~mm}$ of irrigation water calculated by Penman-Monteith equation and applied with drip irrigation every day under inoculation of the seeds by Rhizobium + Azotobacter chroococcum + Bacillus megaterium. Hefzy (2009) found that, the seasonal irrigation water applied under surface irrigation was higher than those under sprinkler irrigation. Values were 1321.2, 1195.2 and $912.5 \mathrm{~mm}$, under surface irrigation while they were 852.5, 791.4 and $594.7 \mathrm{~mm}$ under sprinkler irrigation system, for peanut plants irrigated at the depletion of 25,50 and $75 \%$ of available soil moisture, respectively.

El- Adel (2001) indicated that the highest seed yield of peanut $(1190 \mathrm{~kg} /$ fed.) was achieved by irrigation every day using $100 \%$ of ETc and traditional fertilization. The effects of irrigation systems on pods and fodder yields and oil yield were insignificant, in both seasons. However, the pods and fodder yields, were increased significantly with increasing available soil moisture, in both seasons, while, protein percentage was decreased (Hefzy, 2009).

Phosphorus is the most important nutrient which affects the yield and quality of leguminous crops including groundnut. Phosphorus plays a beneficial role in legume growth promoting extensive root development and thereby ensuring a good yield. Phosphorus fertilization was investigated by several workers and they recommended varied doses of $\mathrm{P}_{2} \mathrm{O}_{5} \mathrm{~kg}$ ha-1 for increasing the yield and its attributes (Patel et al., 1990 and Sharma \& Yadav, 1997). Agasimani and Babalad (1991) reported that response to $\mathrm{P}$ could be obtained when the available $\mathrm{P}$ status in the soil was less than $15 \mathrm{~kg} \mathrm{P}_{2} \mathrm{O}_{5} /$ fed. Singh and Chaudhari (1996) reported that phosphorus application brought about significant increase in biological yield in calcareous soils. Increasing phosphorus levels increased leaves and stem weight/plant, number of pods and seeds/plant, weight of pods and seeds/ plant, 100-seed weight, seed and oil yields, oil percentage, seed protein content as well as NPK contents (Mehta \& Ram Mohan Rao, 1996; Nasr-Alla et al., 1998; Tran Thi Thu Ha 2003; El-Habbasha et al., 2005;

Egypt. J. Soil Sci. 55, No. 1 (2015) 
Mirvat et al., 2006 and Ibrahim \& Mona, 2008). The aim of this study was to find the best irrigation and phosphorus application managements for peanut grown on sandy calcareous soils.

\section{Material and Methods}

Field experiments were carried-out at the Experimental Farm of Arab ElAwammer Research Station, ARC, Assuit, Egypt (which, lies between latitude $27^{\circ}$, $11^{\prime} \mathrm{N}$ and longitude $31^{\circ}, 06^{\prime} \mathrm{E}$ and the altitude of the area is $71 \mathrm{~m}$ ) during two successive growing season 2010 and 2011 to study the effect of two levels of phosphorus fertigation in the form of phosphoric acid $\left(23 \mathrm{~kg} \mathrm{P}_{2} \mathrm{O}_{5} /\right.$ fed $\left(\mathrm{P}_{1}\right)$ and 31 kg $\mathrm{P}_{2} \mathrm{O}_{5} /$ fed. $\left.\left(\mathrm{P}_{2}\right)\right)$ applied in different doses $\left(\mathrm{D}_{1}(3\right.$ doses $), \mathrm{D}_{2}(6$ doses $)$ and $\mathrm{D}_{3}(9$ doses)) under different irrigation regimes namely $80 \%\left(\mathrm{I}_{1}\right)$ and $100 \%\left(\mathrm{I}_{2}\right)$ from pan evaporation. Irrigation water use efficiency (IWUE), phosphate fertilizer use efficiency, peanut yield and yield components were estimated. The average monthly meteorological data of Assuit weather station during the growth seasons are presented in Table 1. The experiment included 12 treatments with three replicates; all treatments were arranged in spilt, spilt plots design. Peanut seeds (Gize 5, variety) were planted in the $1^{\text {st }}$ of June and $12^{\text {th }}$ of June in the first and second summer seasons on 2010 and 2011, respectively. The peanut plants were harvested on October 20 and 31 in first and second seasons, respectively. Soil physical and chemical properties were measured and recorded in Table 2. CROPWAT model was used to calculate reference evapotranspiration with Penman Monteith (Smith, 1991).

Crop evapotranspiration (ETc). (Allen et al., 1998)

$$
E T_{c}=E T_{\mathrm{O}} \times K_{C}
$$

where:

$$
\begin{aligned}
& \mathrm{ETc}=\text { Crop evapotranspiration. } \\
& \mathrm{ET}_{0}=\text { Reference evapotranspiration } . \\
& \mathrm{Kc}=\text { Crop coefficient }
\end{aligned}
$$

\begin{tabular}{|c|c|c|c|c|c|c|c|}
\hline \multicolumn{8}{|c|}{ Summer season 2010} \\
\hline & \multicolumn{2}{|c|}{ Temperature $(\dot{\mathbf{c}})$} & \multirow{2}{*}{$\begin{array}{c}\text { Relative } \\
\text { humidity } \\
\%\end{array}$} & \multirow{2}{*}{$\begin{array}{c}\text { Epan } \\
\text { mm/day }\end{array}$} & \multirow{2}{*}{$\begin{array}{l}\text { Wind } \\
\text { speed } \\
\text { m/sec }\end{array}$} & \multirow{2}{*}{$\begin{array}{c}\text { Solar } \\
\text { radiation } \\
\mathrm{Col} / \mathrm{Cm}^{2} / \mathrm{day}\end{array}$} & \multirow{2}{*}{$\begin{array}{l}\text { Sunshine } \\
\text { hours }\end{array}$} \\
\hline & Max & Min & & & & & \\
\hline June & 34.3 & 16.9 & 46.7 & 6.3 & 4.2 & 639 & 12.3 \\
\hline July & 37.8 & 17.9 & 42.4 & 6.7 & 2.8 & 631 & 12.2 \\
\hline August & 35.0 & 20.8 & 52.2 & 7.1 & 4.9 & 608 & 11.9 \\
\hline September & 37.0 & 20.9 & 54.0 & 5.0 & 4.2 & 538 & 10.8 \\
\hline October & 34.9 & 18.4 & 54.4 & 4.6 & 4.3 & 454 & 10.0 \\
\hline \multicolumn{8}{|c|}{ Summer season 2011} \\
\hline June & 37.2 & 21.8 & 31.6 & 6.3 & 2.4 & 639 & 12.3 \\
\hline July & 39.1 & 23.0 & 34.0 & 7.2 & 1.9 & 631 & 12.2 \\
\hline August & 37.1 & 21.3 & 41.0 & 7.1 & 1.6 & 608 & 11.9 \\
\hline September & 35.0 & 19.3 & 46.4 & 5.6 & 1.1 & 538 & 10.8 \\
\hline October & 31.6 & 16.4 & 45.5 & 3.6 & 1.6 & 454 & 10.0 \\
\hline
\end{tabular}

TABLE 1. Average monthly meteorological data of Assuit weather station during the two growth seasons of 2010 and 2011. 
TABLE 2. Physical and chemical characteristics of representative composite soil sample from the field experimental site.

\begin{tabular}{|c|c|c|c|c|c|c|c|c|c|}
\hline \multicolumn{10}{|c|}{ Chemical properties } \\
\hline \multirow{2}{*}{$\begin{array}{c}\text { pH } \\
(\mathbf{1}: \mathbf{1})\end{array}$} & \multirow{2}{*}{$\begin{array}{c}\text { EC } \\
\mathrm{dS} / \mathrm{m} \\
(\mathbf{1}: \mathbf{1})\end{array}$} & \multicolumn{4}{|c|}{ Soluble cations $(\mathrm{meq} / \mathrm{L})$} & \multicolumn{2}{|c|}{$\begin{array}{c}\text { Soluble anions } \\
(\mathrm{meq} / \mathrm{L}\end{array}$} & \multirow{2}{*}{$\begin{array}{c}\text { Available } \\
\text { Phosphorus } \\
\text { (ppm }\end{array}$} & \multirow{2}{*}{$\begin{array}{c}\text { Total } \\
\text { nitrogen } \\
(\%)\end{array}$} \\
\hline & & $\mathbf{C a}^{++}$ & $\mathbf{M g}^{++}$ & $\mathrm{Na}^{+}$ & $\mathbf{K}^{+}$ & $\begin{aligned} & \mathrm{CO}_{3}^{--} \\
&+ \mathrm{HCO}_{3}^{-} \\
&\end{aligned}$ & $\mathbf{C l}$ & & \\
\hline 8.37 & 0.33 & 1.43 & 1.16 & 0.19 & 0.75 & 1.68 & 1.47 & 8.31 & 0.003 \\
\hline \multicolumn{10}{|c|}{ Physical properties } \\
\hline \multicolumn{3}{|c|}{$\begin{array}{c}\text { Particle size distribution } \\
(\%)\end{array}$} & Texture & \multicolumn{3}{|c|}{$\begin{array}{c}\text { Moisture content } \\
\text { (Volumetric \%) }\end{array}$} & \multirow{2}{*}{$\begin{array}{l}\text { O.M } \\
(\%)\end{array}$} & \multirow{2}{*}{$\underset{(\%)}{\mathrm{CaCO}_{3}}$} & \multirow{2}{*}{$\begin{array}{c}\text { bulk } \\
\text { density }\end{array}$} \\
\hline Sand & Silt & Clay & & S.P. & F.C. & W.P. & & & \\
\hline 89.9 & 7.1 & 3.0 & sandy & 23.3 & 10.9 & 4.5 & 0.19 & 30.9 & 1.63 \\
\hline
\end{tabular}

Irrigation water use efficiency (IWUE)

The irrigation water use efficiency (IWUE) values were calculated as follows:

$$
I W U E=\frac{\text { Grain or Seed yield }(\mathrm{Kg} / \mathrm{fed} .)}{\text { Irrigation water requiremens }\left(\mathrm{m}^{3} / \mathrm{fed} .\right)}
$$

Phosphorus fertilizer use efficiency (PUE)

Phosphorus fertilizer use efficiency (PUE) was calculated to express the amount of yield $(\mathrm{kg})$ produced by an input of 1 unit $(\mathrm{kg})$ of fertilizer. The following equation was used:

$$
P U E=\frac{\text { Yield }(\mathrm{Kg} / \mathrm{fed} .)}{\text { Total phosphorusfertilizer added }(\mathrm{Kg} / \mathrm{fed})}
$$

Statistical analysis

All obtained data were subjected to statistical analysis of variance and treatment means were compared for significant differences using the LSD at $p=$ 0.05.. The MSTAT-C (version 2.10) computer program was used to perform all the analysis of variance in agreement with the procedure outlined by Steel and Torrie (1982).

\section{Results and Discussion}

\section{Irrigation water applied}

The data in Table 3 and in Fig. 1 indicate that the irrigation water applied vary from growth stage to another through the two growth seasons. These variations are low at the beginning of the growing season, because peanut canopy has not established yet so the loss of moisture is mostly by evaporation from soil surface. As the plant developed, a gradual increase is observed in water consumption. The irrigation water applied reaches its peak in the medium growth stage. This may be due to the high air temperature which prevailing through this

Egypt. J. Soil Sci. 55, No. 1 (2015) 
period and the growth status of plant. After reaching the peak of vegetation development, the rate of irrigation water applied pronouncedly decreases during the late season of plants. The seasonal irrigation water applied was mostly influenced by irrigation treatments. The increase in irrigation water applied under $\mathrm{I}_{1}$ treatment may be attributed to the increase in direct evaporation. Therefore, the seasonal irrigation water applied is higher under $I_{1}$ followed by $I_{2}$ for peanut during the two growth seasons. These results are in the same line with those reported by Doorenbos et al. (1979); Tayel \& and Wahba (1989); Plaut \& BenHur (2005); Mohamed \& Usman (2007) and Hefzy (2009).

TABLE 3. Irrigation water applied $(\mathrm{mm})$ as affected by irrigation regime at different peanut growth stages during summer seasons of 2010 and 2011.

\begin{tabular}{|c|c|c|c|c|c|c|}
\hline \multirow{2}{*}{ Growth stages } & \multicolumn{2}{|c|}{2010} & \multicolumn{2}{|c|}{2011} & \multicolumn{2}{|c|}{$\begin{array}{c}\text { Average of two } \\
\text { seasons }\end{array}$} \\
\hline & $\mathbf{I}_{1}$ & $\mathbf{I}_{2}$ & $\mathbf{I}_{1}$ & $\mathbf{I}_{2}$ & $\mathbf{I}_{1}$ & $\mathbf{I}_{2}$ \\
\hline Initial stage & 61.4 & 49.1 & 63.1 & 50.4 & 62.2 & 49.8 \\
\hline Development stage & 198.5 & 158.8 & 212.1 & 169.7 & 205.3 & 164.2 \\
\hline Mid- season stage & 456.4 & 365.1 & 460.0 & 368.0 & 458.2 & 366.6 \\
\hline Late-season stage & 150.7 & 120.6 & 146.4 & 117.1 & 148.6 & 118.8 \\
\hline Harvest stage & 87.4 & 69.9 & 51.1 & 40.9 & 69.3 & 55.4 \\
\hline Total & 954.4 & 763.5 & 932.6 & 746.1 & 943.5 & 754.8 \\
\hline
\end{tabular}
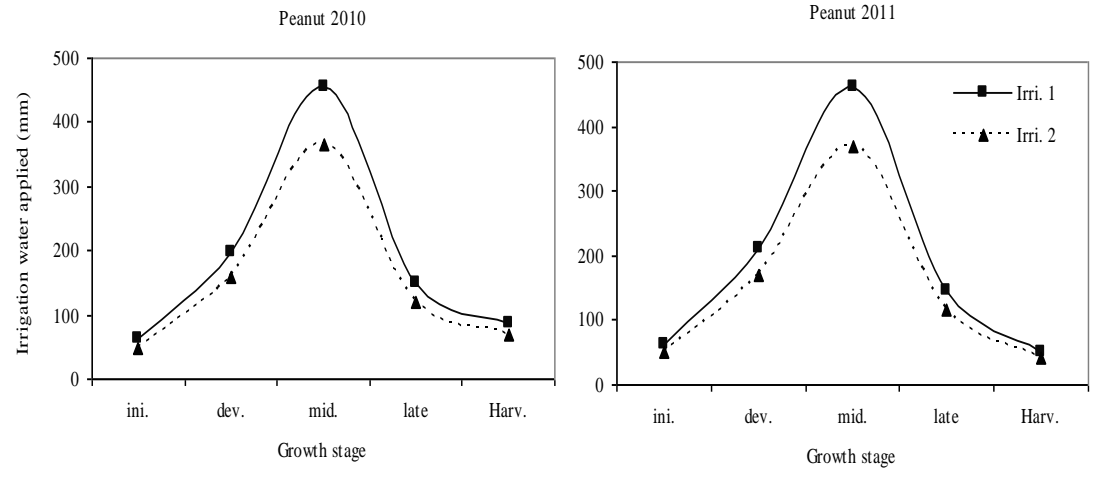

Fig. 1. Irrigation water applied ( $\mathrm{mm})$ at different growth stages of peanut grown under different irrigation regimes during the seasons of $2010 \& 2011$. 
Crop evapotranspiration (ETc)

Data in Table 4 which illustrated in Figure 2 show the values of the crop evapotranspiration (ETc ) calculated according to Penman Monteith equations for peanut crop during the two successive growth seasons. The results show that the total values of ETc for peanut crop were $858.8 \mathrm{~mm}$ in the first growth season and $783.6 \mathrm{~mm}$ in the second growth season according to Penman Monteith equations. The results also, indicated that the total ETc values in the first season were higher than the values of the second season. El - Koliey et al. (2001) calculated the seasonal ETc for peanut crop at Assuit Governorate and found it to be 676.13, 764 and $584.5 \mathrm{~mm}$ as calculated from, Modified Penman, Penman Monteith and Doorenbos\& Pruitt, respectively. Hefzy (2009) calculated seasonal ET $_{c}$ for peanut crop at Assuit Governorate and found it to be 826.6 and $872.0 \mathrm{~mm}$ as calculated from Penman Monteith during seasons 2005 and 2006, respectively.

TABLE 4. Crop evapotranspiration ETc $(\mathrm{mm})$ during growth stages of peanut calculated according to Penman Monteith equations.

\begin{tabular}{|l|c||c||c|}
\hline \multicolumn{1}{|c|}{ Growth stages } & $\mathbf{2 0 1 0}$ & $\mathbf{2 0 1 1}$ & $\begin{array}{c}\text { Average of two } \\
\text { seasons }\end{array}$ \\
\hline \hline Initial stage & 64.2 & 63.6 & 63.9 \\
\hline \hline Development stage & 188.9 & 192.0 & 190.4 \\
\hline \hline Mid- season stage & 388.0 & 346.3 & 367.1 \\
\hline \hline Late-season stage & 143.0 & 121.1 & 132.1 \\
\hline \hline Harvest stage & 74.8 & 60.6 & 67.7 \\
\hline \hline Total & $\mathbf{8 5 8 . 8}$ & $\mathbf{7 8 3 . 6}$ & $\mathbf{8 2 1 . 2}$ \\
\hline
\end{tabular}

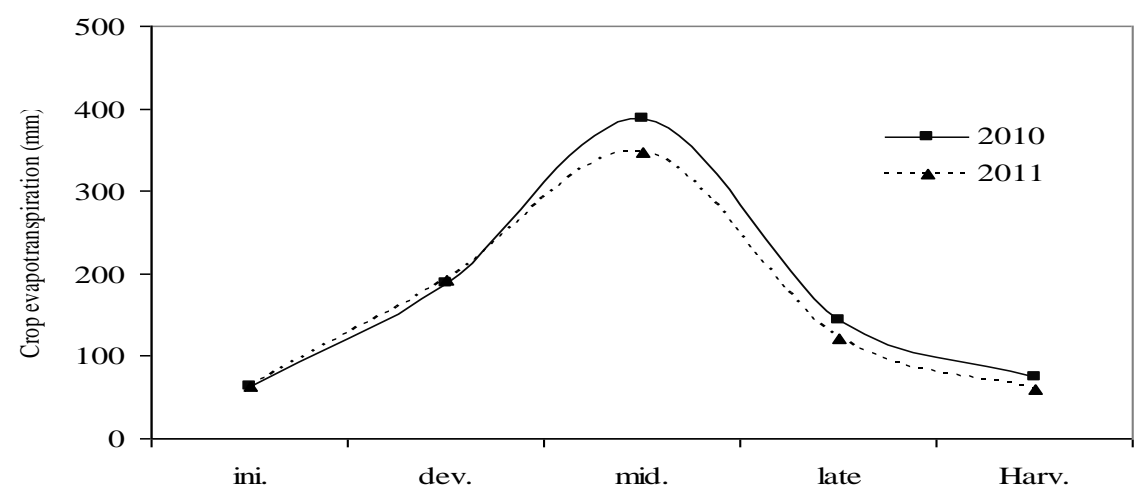

Growth stage

Fig. 2. Crop evapotranspiration $(\mathrm{mm})$ for peanut during the growth stages through the growth seasons of 2010 and 2011.

Egypt. J. Soil Sci. 55, No. 1 (2015) 
Yield of peanut and its components

Effect of irrigation regimes, $P$ rates and number of fertigation doses on yield and its components of peanut.

Irrigation regimes significantly $(\mathrm{p} \leq 0.05)$ affect pods and fodder yields of peanut (Tables 5 and 6 ). First irrigation treatment $\left(\mathrm{I}_{1}\right)$ resulted in significantly $(\mathrm{p} \leq 0.05)$ higher pod and fodder yields compared to second irrigation treatment $\left(I_{2}\right)$. Increasing amount of irrigation from $I_{1}$ to $I_{2}$ led to an increase of 21.70 and $15.55 \%$ in the pods yield and 21.66 and $15.55 \%$ in fodder yield in 2010 and 2011 seasons, respectively.

Meanwhile, irrigation treatments hadn't significant effects on 100-pod weight and 100-seed weight (Tables 7 and 8). The highest values of 100-pod and 100-seed weights were obtained with irrigation at $I_{1}$. Irrigating peanut plants under $I_{1}$ increased the available soil moisture in the root zone which enhances the peanut plants to absorb sufficient water and consequently increase the photosynthesis activity. This in turn increases the cell division and stem elongation and diameter. Also, increasing the available soil moisture may increase the rate of leaf appearance and leaf growth which resulted in increasing the other growth parameters. The availability of water in the soil root zone environment and increasing of net assimilation rate resulted in the increase in dry matter accumulation in the reproductive organs of plants. However, plants that suffered from water deficit in the root zone have limited root system and weak shoot growth, which in turn reduced both vegetative growth and yield of peanut crop. Similar results were obtained by some authors (Hefzy, 2009).

Results presented in Tables 5-10 show clearly that there were significant differences between phosphorus rates influence on the studied characters in 2010 and 2011 seasons. Application of fertigated phosphorus at the rate of 31 $\mathrm{kg} \mathrm{P}_{2} \mathrm{O}_{5}$ fed $^{-1}$ gave the highest values of pod and fodder yields; 100-pod and 100 -seed weights as compared with a rate of $23 \mathrm{~kg} \mathrm{P}_{2} \mathrm{O}_{5} \mathrm{fed}^{-1}$ in both seasons. Increasing in the previous parameters may be due to the increase of phosphorus rate which is known to help developing a more extensive root system and thus enabling plants to extract water and nutrients, from more soil depths. This in turn could enhance the plants to produce more assimilates which was reflected in higher biomass. Furthermore, the increases in yield due to phosphorus fertilizer may be attributed to the activation of metabolic processes, where its role in building phospholipids and nucleic acid is known. Moreover, phosphorus is an important nutrient for all the crops in general and legumes in particular, it is a key constituent of ATP and plays, significant role in energy transformation in plant and also in various roles in seed formation. Phosphorus application increases groundnut yield and yield contributing characters. Dry matter can also be increased with increasing P levels up to a certain limit (Sanker et al., 1984; Marschner, 1986; Savani et al., 
1995 and Gobarah, Mirvat et al., 2006). A long time reaction of soluble $\mathrm{P}$ with soil leads to its reaction with solid phase of soil and with calcium carbonate and the formation of relatively insoluble reaction products with $\mathrm{Ca}$, $\mathrm{Fe}$ and $\mathrm{Al}$ leading to $\mathrm{P}$ fixation. All these processes leading to fixation are delayed when we apply fertilizer through fertigation as plants absorbs this nutrient quickly and directly from solution applied through fertigation. In addition, the positive effect of fertigation may also be due to optimum moisture in the soil at appropriate time along with fertilization, which facilitates maximum utilization of applied P by plant. Gajbhiye et al. (1990) reported that availability of more water for plant absorption and better metabolic activity resulted in higher dry matter yield. Similar results have been also reported by Iqbal et al. (2003).

TABLE 5. Pods yield (kg/ fed.) of peanut as influenced by irrigation regimes, $P$ rates and number of fertigation doses under drip irrigation.

\begin{tabular}{|c|c|c|c|c|c|c|c|c|c|}
\hline \multirow{2}{*}{\multicolumn{2}{|c|}{ Treatments }} & \multicolumn{4}{|c|}{2010} & \multicolumn{4}{|c|}{2011} \\
\hline & & \multirow{2}{*}{$\begin{array}{c}\mathbf{D}_{1} \\
1301.3\end{array}$} & \multirow{2}{*}{$\begin{array}{c}\mathbf{D}_{\mathbf{2}} \\
1490.2\end{array}$} & \multirow{2}{*}{$\begin{array}{c}\mathbf{D}_{\mathbf{3}} \\
1727.7\end{array}$} & \multirow{2}{*}{\begin{tabular}{|c|} 
Mean \\
1506.4
\end{tabular}} & \multirow{2}{*}{$\begin{array}{c}\mathbf{D}_{1} \\
1491.4\end{array}$} & \multirow{2}{*}{$\begin{array}{c}\mathbf{D}_{\mathbf{2}} \\
1652.3\end{array}$} & \multirow{2}{*}{$\begin{array}{c}\mathbf{D}_{3} \\
1854.6\end{array}$} & \multirow{2}{*}{$\begin{array}{c}\text { Mean } \\
1666.1\end{array}$} \\
\hline & $\mathrm{P}_{2}$ & & & & & & & & \\
\hline & $\mathrm{P}_{1}$ & 1179.7 & 1251.9 & 1359.2 & 1263.6 & 1387.8 & 1449.4 & 1540.7 & 1459.3 \\
\hline \multicolumn{2}{|l|}{ Mean } & & 1371.1 & 1543.5 & 1385.0 & 1439.6 & 1550.9 & 1697.7 & 1562.7 \\
\hline \multirow{2}{*}{$\mathrm{I}_{2}$} & $\mathrm{P}_{2}$ & 1046.3 & 1182.6 & 1444.7 & 1224.5 & 1274.2 & 1390.3 & 1613.5 & 1426.0 \\
\hline & $\mathrm{P}_{1}$ & 980.7 & 1025.7 & 1148.4 & 1051.6 & 1218.3 & 1256.6 & 1361.2 & 1278.7 \\
\hline \multicolumn{2}{|l|}{ Mean } & 1013.5 & 1104.1 & 1296.5 & 1138.1 & 1246.3 & 1323.5 & 1487.4 & 1352.4 \\
\hline \multicolumn{2}{|l|}{ Split mean } & 1127.0 & 1237.6 & 1420.0 & & 1342.9 & 1437.2 & 1592.5 & \\
\hline \multirow{2}{*}{ Phosph x Split } & $\mathrm{P}_{2}$ & 1173.8 & 1336.4 & 1586.2 & 1365.5 & 1382.8 & 1521.3 & 1734.1 & 1546.1 \\
\hline & $\mathrm{P}_{1}$ & 1080.2 & 1138.8 & 1253.8 & 1157.6 & 1303.1 & 1353.0 & 1451.0 & 1369.0 \\
\hline \multicolumn{2}{|c|}{ L.S.D 0.05 for I } & \multicolumn{4}{|c|}{88.1} & \multicolumn{4}{|r|}{75.0} \\
\hline \multicolumn{2}{|c|}{ L.S.D 0.05 for $\mathrm{P}$} & \multicolumn{4}{|c|}{136.5} & \multicolumn{4}{|r|}{116.2} \\
\hline \multicolumn{2}{|c|}{ L.S.D 0.05 for $\mathrm{IxP}$} & \multicolumn{4}{|c|}{ n.s } & \multicolumn{4}{|r|}{ n.s } \\
\hline \multicolumn{2}{|c|}{ L.S.D 0.05 for $\mathrm{D}$} & \multicolumn{4}{|c|}{99.9} & \multicolumn{4}{|r|}{85.1} \\
\hline \multicolumn{2}{|c|}{ L.S.D 0.05 for IxD } & \multicolumn{4}{|c|}{ n.s } & \multicolumn{4}{|r|}{ n.s } \\
\hline \multicolumn{2}{|c|}{ L.S.D 0.05 for PxD } & \multicolumn{4}{|c|}{ n.s } & \multicolumn{4}{|r|}{ n.s } \\
\hline \multicolumn{2}{|c|}{ L.S.D 0.05 for IxPxD } & & & & n.s & & & & n.s \\
\hline
\end{tabular}

Egypt. J. Soil Sci. 55, No. 1 (2015) 
EFFECT OF DRIP IRRIGATION AND PHOSPHORUS FERTILIZATION...

TABLE 6. Fodder yield (kg/ fed.) of peanut as influenced by irrigation regimes, $P$ rates and number of fertigation doses under drip irrigation.

\begin{tabular}{|c|c|c|c|c|c|c|c|c|c|}
\hline \multirow{2}{*}{\multicolumn{2}{|c|}{ Treatments }} & \multicolumn{4}{|c|}{2010} & \multicolumn{4}{|c|}{2011} \\
\hline & & \multirow{2}{*}{$\begin{array}{c}\mathbf{D}_{\mathbf{1}} \\
2281.7\end{array}$} & \multirow{2}{*}{\begin{tabular}{|c|}
$\mathbf{D}_{\mathbf{2}}$ \\
2612.6
\end{tabular}} & \multirow{2}{*}{\begin{tabular}{|c|}
$\mathbf{D}_{\mathbf{3}}$ \\
3028.4
\end{tabular}} & \multirow{2}{*}{$\frac{\text { Mean }}{2640.9}$} & \multirow{2}{*}{\begin{tabular}{|c|}
$\mathbf{D}_{\mathbf{1}}$ \\
2618.8
\end{tabular}} & \multirow{2}{*}{$\frac{\mathbf{D}_{\mathbf{2}}}{2901.5}$} & \multirow{2}{*}{$\begin{array}{c}\mathbf{D}_{\mathbf{3}} \\
3256.7\end{array}$} & \multirow{2}{*}{$\begin{array}{l}\text { Mean } \\
2925.7\end{array}$} \\
\hline & $\mathrm{P}_{2}$ & & & & & & & & \\
\hline $1_{1}$ & $\mathrm{P}_{1}$ & 2068.8 & 2195.3 & 2383.1 & 2215.8 & 2437.0 & 2545.1 & 2705.5 & 2562.5 \\
\hline \multicolumn{2}{|l|}{ Mean } & & 2403.9 & 2705.8 & 2428.3 & 2527.9 & 2723.3 & 2981.1 & 2744.1 \\
\hline \multirow{2}{*}{$\mathrm{I}_{2}$} & $\mathrm{P}_{2}$ & 1835.2 & 2073.9 & 2532.8 & 2147.3 & 2237.5 & 2441.3 & 2833.3 & 2504.0 \\
\hline & $\mathrm{P}_{1}$ & 1720.4 & 1799.2 & 2014.1 & 1844.5 & 2139.4 & 2206.7 & 2390.2 & 2245.4 \\
\hline \multicolumn{2}{|l|}{ Mean } & 1777.8 & 1936.5 & 2273.4 & 1995.9 & 2188.4 & 2324.0 & 2611.8 & 2374.7 \\
\hline \multicolumn{2}{|c|}{ Split mean } & 1976.5 & 2170.2 & 2489.6 & & 2358.2 & 2523.6 & 2796.5 & \\
\hline \multirow{2}{*}{$\begin{array}{l}\text { Phosph x } \\
\text { Split }\end{array}$} & $\mathrm{P}_{2}$ & 2058.4 & 2343.2 & 2780.6 & 2394.1 & 2428.1 & 2671.4 & 3045.0 & 2714.9 \\
\hline & $\mathrm{P}_{1}$ & 1894.6 & 1997.2 & 2198.6 & 2030.1 & 2288.2 & 2375.9 & 2547.9 & 2404.0 \\
\hline \multicolumn{2}{|c|}{ L.S.D 0.05 for I } & \multicolumn{4}{|c|}{154.2} & \multicolumn{4}{|r|}{131.7} \\
\hline \multicolumn{2}{|c|}{ L.S.D 0.05 for $P$} & \multicolumn{4}{|r|}{238.9} & \multicolumn{4}{|r|}{204.1} \\
\hline \multicolumn{2}{|c|}{ L.S.D 0.05 for IxP } & \multicolumn{4}{|r|}{ n.s } & \multicolumn{4}{|r|}{ n.s } \\
\hline \multicolumn{2}{|c|}{ L.S.D 0.05 for $\mathrm{D}$} & \multicolumn{4}{|r|}{174.9} & \multicolumn{4}{|r|}{149.4} \\
\hline \multicolumn{2}{|c|}{ L.S.D 0.05 for $\mathrm{IxD}$} & \multicolumn{4}{|r|}{ n.s } & \multicolumn{4}{|r|}{ n.s } \\
\hline \multicolumn{2}{|c|}{ L.S.D 0.05 for PxD } & \multicolumn{4}{|r|}{ n.s } & \multicolumn{4}{|r|}{ n.s } \\
\hline \multicolumn{2}{|c|}{ L.S.D 0.05 for $\mathrm{IxPxD}$} & & & & n.s & & & & n.s \\
\hline
\end{tabular}

TABLE 7. Weight of 100-pod (g) of peanut as influenced by irrigation regimes, $P$ rates and number of fertigation doses under drip irrigation.

\begin{tabular}{|c|c|c|c|c|c|c|c|c|c|}
\hline \multirow{2}{*}{\multicolumn{2}{|c|}{ Treatments }} & \multicolumn{4}{|c|}{2010} & \multicolumn{4}{|c|}{2011} \\
\hline & & \multirow{2}{*}{$\begin{array}{r}\mathbf{D}_{\mathbf{1}} \\
231.7 \\
\end{array}$} & \multirow{2}{*}{\begin{tabular}{|r|}
$\mathbf{D}_{2}$ \\
235.3 \\
\end{tabular}} & \multirow{2}{*}{\begin{tabular}{|c|}
$\mathbf{D}_{\mathbf{3}}$ \\
239.9 \\
\end{tabular}} & \multirow{2}{*}{$\begin{array}{c}\text { Mean } \\
235.6\end{array}$} & \multirow{2}{*}{$\begin{array}{c}\mathbf{D}_{1} \\
201.5 \\
\end{array}$} & \multirow{2}{*}{$\begin{array}{c}\mathbf{D}_{2} \\
204.6 \\
\end{array}$} & \multirow{2}{*}{\begin{tabular}{|c|}
$\mathbf{D}_{\mathbf{3}}$ \\
208.6 \\
\end{tabular}} & \multirow{2}{*}{$\begin{array}{l}\text { Mean } \\
204.9 \\
\end{array}$} \\
\hline & $\mathrm{P}_{2}$ & & & & & & & & \\
\hline$I_{1}$ & $\mathrm{P}_{1}$ & 216.9 & 226.4 & 231.6 & 225.0 & 188.7 & 196.9 & 201.3 & 195.6 \\
\hline \multicolumn{2}{|l|}{ Mean } & & 230.8 & 235.7 & 230.3 & 195.1 & 200.7 & 205.0 & 200.3 \\
\hline \multirow{2}{*}{$\mathrm{I}_{2}$} & $\mathrm{P}_{2}$ & 213.8 & 222.1 & 233.4 & 223.1 & 185.9 & 193.1 & 202.9 & 194.0 \\
\hline & $\mathrm{P}_{1}$ & 210.8 & 221.0 & 226.6 & 219.5 & 183.3 & 192.2 & 197.1 & 190.8 \\
\hline \multicolumn{2}{|l|}{ Mean } & 212.3 & 221.6 & 230.0 & 221.3 & 184.6 & 192.7 & 200.0 & 192.4 \\
\hline \multicolumn{2}{|l|}{ Split mean } & 218.3 & 226.2 & 232.9 & & 189.8 & 196.7 & 202.5 & \\
\hline \multirow{2}{*}{$\begin{array}{ll}\text { Phosph } \quad \mathrm{x} \\
\text { Split } \\
\end{array}$} & $\mathrm{P}_{2}$ & 222.7 & 228.7 & 236.6 & 229.4 & 193.7 & 198.9 & 205.7 & 199.4 \\
\hline & $\mathrm{P}_{1}$ & 213.9 & 223.7 & 229.1 & 222.2 & 186.0 & 194.5 & 199.2 & 193.2 \\
\hline \multicolumn{2}{|c|}{ L.S.D 0.05 for I } & \multicolumn{4}{|c|}{\begin{tabular}{|r} 
n.s \\
\end{tabular}} & \multicolumn{4}{|c|}{ n.s } \\
\hline \multicolumn{2}{|c|}{ L.S.D 0.05 for $\mathrm{P}$} & \multicolumn{4}{|c|}{$\begin{array}{r}3.9 \\
\end{array}$} & \multicolumn{4}{|c|}{3.4} \\
\hline \multicolumn{2}{|c|}{ L.S.D 0.05 for IxP } & & n.s & \multicolumn{4}{|r|}{ n.s } \\
\hline \multicolumn{2}{|c|}{ L.S.D 0.05 for $\mathrm{D}$} & & 2.7 & \multicolumn{4}{|r|}{2.4} \\
\hline \multicolumn{2}{|c|}{ L.S.D 0.05 for $\mathrm{IxD}$} & \multicolumn{3}{|l|}{ 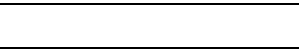 } & n.s & \multicolumn{4}{|r|}{ n.s } \\
\hline \multicolumn{2}{|c|}{ L.S.D 0.05 for PxD } & & n.s & \multicolumn{4}{|r|}{ n.s } \\
\hline \multicolumn{2}{|c|}{ L.S.D 0.05 for $\mathrm{IxPxD}$} & & & & n.s & & & & n.s \\
\hline
\end{tabular}

Egypt. J. Soil Sci. 55, No. 1 (2015) 
TABLE 8. Weight of 100 -seed ( $g$ ) of peanut as influenced by irrigation regimes, $P$ rates and number of fertigation doses under drip irrigation.

\begin{tabular}{|c|c|c|c|c|c|c|c|c|c|}
\hline \multirow{2}{*}{\multicolumn{2}{|c|}{ Treatments }} & \multicolumn{4}{|c|}{2010} & \multicolumn{4}{|c|}{2011} \\
\hline & & \multirow{2}{*}{$\begin{array}{l}\mathbf{D}_{\mathbf{1}} \\
84.9\end{array}$} & \multirow{2}{*}{$\begin{array}{l}\mathbf{D}_{\mathbf{2}} \\
86.2\end{array}$} & \multirow{2}{*}{$\begin{array}{l}\mathbf{D}_{\mathbf{3}} \\
88.0\end{array}$} & \multirow{2}{*}{\begin{tabular}{|c|} 
Mean \\
86.4
\end{tabular}} & \multirow{2}{*}{$\begin{array}{l}\mathbf{D}_{\mathbf{1}} \\
71.0\end{array}$} & \multirow{2}{*}{$\begin{array}{l}\mathbf{D}_{2} \\
72.1\end{array}$} & \multirow{2}{*}{$\begin{array}{l}\mathbf{D}_{\mathbf{3}} \\
73.5\end{array}$} & \multirow{2}{*}{\begin{tabular}{|r|} 
Mean \\
72.2 \\
\end{tabular}} \\
\hline I & $\mathrm{P}_{2}$ & & & & & & & & \\
\hline $1_{1}$ & $\mathrm{P}_{1}$ & 79.3 & 82.9 & 84.8 & 82.4 & 66.3 & 69.3 & 70.9 & 68.8 \\
\hline \multicolumn{2}{|l|}{ Mean } & & 84.6 & 86.4 & 84.4 & 68.6 & 70.7 & 72.2 & 70.5 \\
\hline \multirow{2}{*}{$\mathrm{I}_{2}$} & $\mathrm{P}_{2}$ & 78.2 & 81.3 & 85.5 & 81.6 & 65.3 & 67.9 & 71.5 & 68.3 \\
\hline & $\mathrm{P}_{1}$ & 77.0 & 80.9 & 83.0 & 80.3 & 64.4 & 67.6 & 69.4 & 67.1 \\
\hline \multicolumn{2}{|l|}{ Mean } & 77.6 & 81.1 & 84.2 & 81.0 & 64.8 & 67.8 & 70.4 & 67.7 \\
\hline \multicolumn{2}{|l|}{ Split mean } & 79.8 & 82.8 & 85.3 & & 66.7 & 69.2 & 71.3 & \\
\hline \multirow{2}{*}{$\begin{array}{l}\text { Phosph } \quad \mathrm{x} \\
\text { Split }\end{array}$} & $\mathrm{P}_{2}$ & 81.5 & 83.8 & 86.7 & 84.0 & 68.1 & 70.0 & 72.5 & 70.2 \\
\hline & $\mathrm{P}_{1}$ & 78.2 & 81.9 & 83.9 & 81.3 & 65.3 & 68.4 & 70.1 & 68.0 \\
\hline \multicolumn{2}{|c|}{ L.S.D 0.05 for I } & \multicolumn{4}{|c|}{$\begin{array}{ll}\text { n.s } \\
\end{array}$} & \multicolumn{4}{|c|}{ n.s } \\
\hline \multicolumn{2}{|c|}{ L.S.D 0.05 for $P$} & & & \multicolumn{2}{|r|}{1.5} & \multicolumn{4}{|r|}{1.2} \\
\hline \multicolumn{2}{|c|}{ L.S.D 0.05 for IxP } & \multicolumn{4}{|c|}{ n.s } & \multicolumn{4}{|c|}{ n.s } \\
\hline \multicolumn{2}{|c|}{ L.S.D 0.05 for $\mathrm{D}$} & \multicolumn{4}{|c|}{$\begin{array}{ll} & 1.0\end{array}$} & \multicolumn{4}{|c|}{0.9} \\
\hline \multicolumn{2}{|c|}{ L.S.D 0.05 for $\mathrm{IxD}$} & & n.s & \multicolumn{4}{|r|}{ n.s } \\
\hline \multicolumn{2}{|c|}{ L.S.D 0.05 for PxD } & & n.s & \multicolumn{4}{|r|}{ n.s } \\
\hline L.S.D $0.05 \mathrm{fc}$ & $\mathrm{IxPxD}$ & & & & n.s & & & & n.s \\
\hline
\end{tabular}

TABLE 9. Irrigation water use efficiency $\left(\mathrm{Kg} / \mathrm{m}^{3}\right)$ of peanut as influenced by irrigation regimes, $P$ rates and number of fertigation doses under drip irrigation.

\begin{tabular}{|c|c|c|c|c|c|c|c|c|c|}
\hline \multirow{2}{*}{\multicolumn{2}{|c|}{ Treatments }} & \multicolumn{4}{|c|}{2010} & \multicolumn{4}{|c|}{2011} \\
\hline & & \multirow{2}{*}{$\frac{\mathbf{D}_{\mathbf{1}}}{0.32}$} & \multirow{2}{*}{$\begin{array}{c}\mathbf{D}_{\mathbf{2}} \\
0.37\end{array}$} & \multirow{2}{*}{$\begin{array}{c}\mathbf{D}_{\mathbf{3}} \\
0.43\end{array}$} & \multirow{2}{*}{$\begin{array}{c}\text { Mean } \\
0.38\end{array}$} & \multirow{2}{*}{$\begin{array}{c}\mathbf{D}_{\mathbf{1}} \\
0.38\end{array}$} & \multirow{2}{*}{$\frac{\mathbf{D}_{\mathbf{2}}}{0.42}$} & \multirow{2}{*}{$\begin{array}{c}\mathbf{D}_{3} \\
0.47\end{array}$} & \multirow{2}{*}{$\begin{array}{c}\text { Mean } \\
0.43\end{array}$} \\
\hline $\mathrm{I}$ & $\mathrm{P}_{2}$ & & & & & & & & \\
\hline$I_{1}$ & $\mathrm{P}_{1}$ & 0.29 & 0.31 & 0.34 & 0.31 & 0.36 & 0.37 & 0.39 & 0.37 \\
\hline \multicolumn{2}{|l|}{ Mean } & & 0.34 & 0.38 & 0.34 & 0.37 & 0.40 & 0.43 & 0.40 \\
\hline \multirow{2}{*}{$\mathrm{I}_{2}$} & $\mathrm{P}_{2}$ & 0.33 & 0.37 & 0.45 & 0.38 & 0.41 & 0.44 & 0.51 & 0.45 \\
\hline & $\mathrm{P}_{1}$ & 0.31 & 0.32 & 0.36 & 0.33 & 0.39 & 0.40 & 0.44 & 0.41 \\
\hline \multicolumn{2}{|l|}{ Mean } & 0.32 & 0.35 & 0.40 & 0.36 & 0.40 & 0.42 & 0.48 & 0.43 \\
\hline \multicolumn{2}{|l|}{ Split mean } & 0.31 & 0.34 & 0.39 & & 0.38 & 0.41 & 0.45 & \\
\hline \multirow{2}{*}{$\begin{array}{l}\text { Phosph } \quad x \\
\text { Split }\end{array}$} & $\mathrm{P}_{2}$ & 0.33 & 0.37 & 0.44 & 0.38 & 0.40 & 0.43 & 0.49 & 0.44 \\
\hline & $\mathrm{P}_{1}$ & 0.30 & 0.32 & 0.35 & 0.32 & 0.37 & 0.39 & 0.41 & 0.39 \\
\hline \multicolumn{2}{|c|}{ L.S.D 0.05 for I } & \multicolumn{4}{|c|}{$\begin{array}{ll}1 & 1 \\
& 0.02 \\
\end{array}$} & \multicolumn{4}{|r|}{0.02} \\
\hline \multicolumn{2}{|c|}{ L.S.D 0.05 for $P$} & \multicolumn{4}{|c|}{0.04} & \multicolumn{4}{|r|}{0.03} \\
\hline \multicolumn{2}{|c|}{ L.S.D 0.05 for IxP } & \multicolumn{4}{|r|}{ n.s } & \multicolumn{4}{|r|}{ n.s } \\
\hline \multicolumn{2}{|c|}{ L.S.D 0.05 for D } & \multicolumn{4}{|r|}{0.03} & \multicolumn{4}{|r|}{0.02} \\
\hline \multicolumn{2}{|c|}{ L.S.D 0.05 for IxD } & \multicolumn{4}{|r|}{ n.s } & \multicolumn{4}{|r|}{ n.s } \\
\hline \multicolumn{2}{|c|}{ L.S.D 0.05 for PxD } & \multicolumn{4}{|r|}{ n.s } & \multicolumn{4}{|r|}{ n.s } \\
\hline \multicolumn{2}{|c|}{ L.S.D 0.05 for $\mathrm{IxPxD}$} & & & & n.s & & & & n.s \\
\hline
\end{tabular}

Egypt. J. Soil Sci. 55, No. 1 (2015) 
TABLE 10. Phosphorus use efficiency (kg/ units) of peanut as influenced by irrigation regimes, $P$ rates and number of fertigation doses under drip irrigation.

\begin{tabular}{|c|c|c|c|c|c|c|c|c|c|}
\hline \multirow{2}{*}{\multicolumn{2}{|c|}{ Treatments }} & \multicolumn{4}{|c|}{2010} & \multicolumn{4}{|c|}{2011} \\
\hline & & \multirow{2}{*}{$\begin{array}{c}\mathbf{D}_{1} \\
56.6\end{array}$} & \multirow{2}{*}{$\frac{\mathbf{D}_{\mathbf{2}}}{64.8}$} & \multirow{2}{*}{$\begin{array}{c}\mathbf{D}_{\mathbf{3}} \\
75.1 \\
\end{array}$} & \multirow{2}{*}{$\begin{array}{c}\text { Mean } \\
65.5 \\
\end{array}$} & \multirow{2}{*}{$\begin{array}{c}\mathbf{D}_{1} \\
64.8 \\
\end{array}$} & \multirow{2}{*}{$\begin{array}{c}\mathbf{D}_{\mathbf{2}} \\
71.8 \\
\end{array}$} & \multirow{2}{*}{$\begin{array}{c}\mathbf{D}_{3} \\
80.6 \\
\end{array}$} & \multirow{2}{*}{$\begin{array}{c}\text { Mean } \\
72.4 \\
\end{array}$} \\
\hline $\mathrm{I}$ & $\mathrm{P}_{2}$ & & & & & & & & \\
\hline $1_{1}$ & $\mathrm{P}_{1}$ & 38.1 & 40.4 & 43.8 & 40.8 & 44.8 & 46.8 & 49.7 & 47.1 \\
\hline \multicolumn{2}{|l|}{ Mean } & 47.3 & 52.6 & 59.5 & 53.1 & 54.8 & 59.3 & 65.2 & 59.8 \\
\hline \multirow{2}{*}{$\mathrm{I}_{2}$} & $\mathrm{P}_{2}$ & 45.5 & 51.4 & 62.8 & 53.2 & 55.4 & 60.5 & 70.2 & 62.0 \\
\hline & $\mathrm{P}_{1}$ & 31.6 & 33.1 & 37.0 & 33.9 & 39.3 & 40.5 & 43.9 & 41.3 \\
\hline \multicolumn{2}{|l|}{ Mean } & 38.6 & 42.3 & 49.9 & 43.6 & 47.4 & 50.5 & 57.0 & 51.6 \\
\hline \multicolumn{2}{|l|}{ Split mean } & 42.9 & 47.4 & 54.7 & & 51.1 & 54.9 & 61.1 & \\
\hline \multirow{2}{*}{$\begin{array}{ll}\text { Phosph } & x \\
\text { Split } & \\
\end{array}$} & $\mathrm{P}_{2}$ & 51.0 & 58.1 & 69.0 & 59.4 & 60.1 & 66.1 & 75.4 & 67.2 \\
\hline & $\mathrm{P}_{1}$ & 34.8 & 36.7 & 40.4 & 37.3 & 42.0 & 43.6 & 46.8 & 44.2 \\
\hline \multicolumn{2}{|c|}{ L.S.D 0.05 for I } & \multicolumn{4}{|r|}{2.9} & \multicolumn{4}{|r|}{2.5} \\
\hline \multicolumn{2}{|c|}{ L.S.D 0.05 for $P$} & & & \multicolumn{2}{|r|}{4.8} & & & \multicolumn{2}{|c|}{4.1} \\
\hline \multicolumn{2}{|c|}{ L.S.D 0.05 for IxP } & & & \multicolumn{2}{|r|}{ n.s } & & & \multicolumn{2}{|r|}{ n.s } \\
\hline \multicolumn{2}{|c|}{ L.S.D 0.05 for $\mathrm{D}$} & & & \multicolumn{2}{|r|}{3.3} & & & \multicolumn{2}{|r|}{2.8} \\
\hline \multicolumn{2}{|c|}{ L.S.D 0.05 for $\mathrm{IxD}$} & & & \multicolumn{2}{|r|}{ n.s } & & & \multicolumn{2}{|r|}{ n.s } \\
\hline \multicolumn{2}{|c|}{ L.S.D 0.05 for PxD } & & & \multicolumn{2}{|r|}{4.7} & & & \multicolumn{2}{|r|}{4.0} \\
\hline \multicolumn{2}{|c|}{$\begin{array}{lll}\text { L.S.D } & 0.05 & \text { for } \\
\text { IxPxD } & & \end{array}$} & & & & n.s & & & & n.s \\
\hline
\end{tabular}

The relationship between water and phosphorus use efficiency

Regression analysis was used to study the relationships between water and phosphorus use efficiency under different fertigation doses (Fig. 3). Data show that, there was a positive linear relationship between WUE and PUE with significant correlation coefficients of $0.486^{* * *}$ and $0.583^{* * *}$ when applied fertigated-P at six and nine doses, respectively, meanwhile application of fertigated-P at three doses gave insignificant correlation coefficient $\left(0.311^{\mathrm{n.s}}\right)$. This means that increasing fertigation increased WUE and PUE. Any increase in WUE is followed by significant increase in PUE. So, any saving in irrigation water increases WUE, PUE and farmer profit. In addition, decreasing fertilizers consumption, consequently decreases pollution of both soil and water. These results are agreeable with those obtained by Tayel et al. (2006) and (2010).

\section{Conclusion}

Irrigated peanut plants with quantity of water equals to $100 \%$ from pan evaporation and application of $31 \mathrm{P}_{2} \mathrm{O}_{5} \mathrm{~kg} / \mathrm{fed}$. on 9 doses gave the highest values of peanut yield on sandy calcareous soils. 

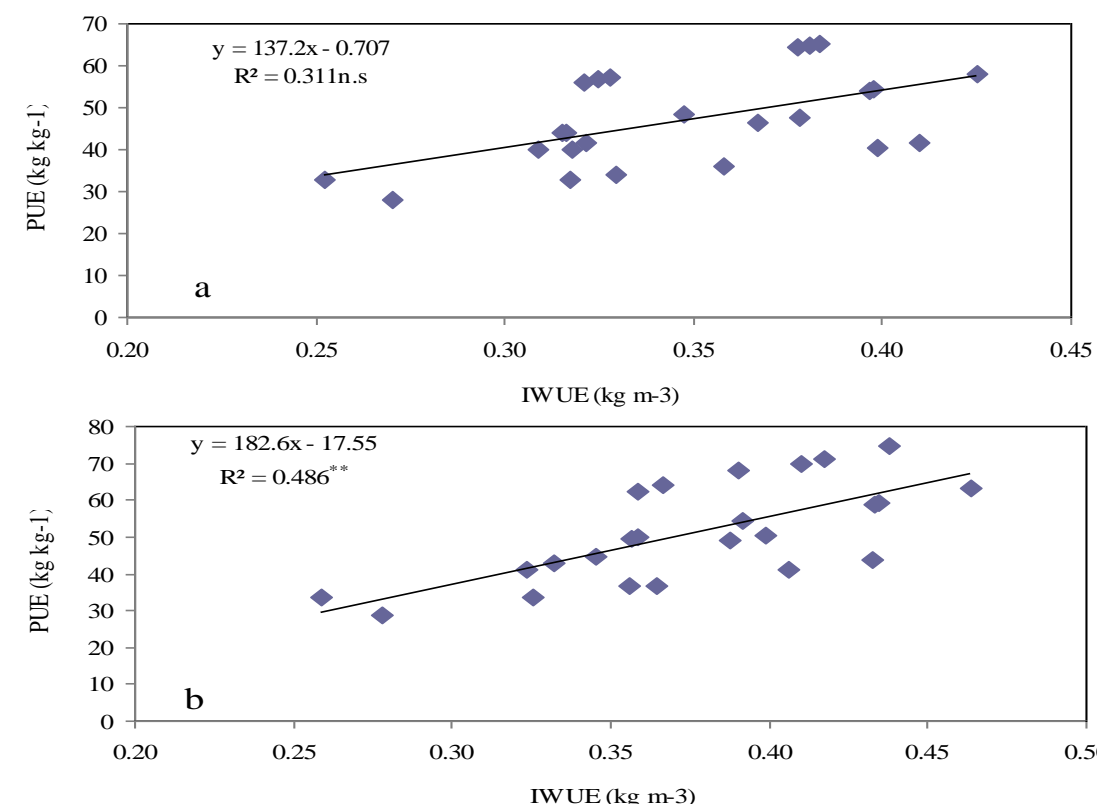

Fig. 3. The relationship between water and phosphorus use efficiency through the growing seasons of 2010 and 2011.

\section{References}

Agasimani, C.A. and Babalad, H.B. (1991) Recent advances in agronomy of groundnut (Arachis hypagaea L.). J. Oilseeds Res. 8,133 - 158.

Allen, G. R., Pereira, L. S., Raes, D. and Smith, M. (1998) Crop evapotranspiration, guidelines for competing crop water requirements. FAO. Irrigation and Drainages Paper 56. Rome, Italy.

Doorenbos, J. and Kassam, A. H. (1979) Yield response to water. FAO. Irrigation and Drainage Paper 33, Rome, Italy.

El-Adel, M.A. (2001) Sprinkler irrigation and fertilization effects on peanut production. Misr J. Agr. Eng., 18 (1), 75-88.

El-Boraie, F.M., Abo-El-Ela, H.K. and Gaber A.M. (2009) Water requirements of peanut grown in sandy soil under drip irrigation and biofertilization. Australian Journal of Basic and Applied Sciences, 3(1), 55-65.

El-Habbasha, S.F., Kandil, A.A., Abu-Hagaza, N.S., Abd El-Haleem, A.K., Khalafallah, M.A. and Behairy, T. Gh. (2005) Effect of phosphorus levels and some bio fertilizers on dry matter, yield and yield attributes of groundnut. Bull. Fac. Agric., Cairo Univ. 56, 237-252.

El-Koliey, M. M., Soliman, S. E. and Eid, H. M. (2001) Estimation of crop water needs in Assiut Governorate. $6^{\text {th }}$ Conference-Meteorology \& Sustainable Development. April 2- 4, Cairo, Egypt.

Egypt. J. Soil Sci. 55, No. 1 (2015) 
Gajbhiye, K.S., Gajkawad, S.T., Chalia, O., Hazare, T.N. and Deshmukh, S.N. (1990) Evaluation of optimum range of soil moisture stress for establishment of wheat crop in Entisols. J. Ind. Soc. Soil, 38,139-141.

Gobarah, Mirvat, E., Magda, H. Mohamed and Tawfik,, M.M. (2006) Effect of phosphorus fertilizer and foliar spraying with zinc on growth, yield and quality of groundnut under reclaimed sandy soils. J. of Applied Sci. Research, Pakistan, 2 (8), 491-496.

Hefzy, M. M. (2009) Water requirements for some crops grown on newly reclaimed soils of Assiut Governorate. M.Sc. Fac. Agric.,Assiut, Univ. Egypt.

Iqbal, Z., Latif, A., Ali, S. and Iqbal, M.M. (2003) Effect of fertigated phosphorus on P use efficiency and yield of wheat and maize. Songklanakarin J. Sci. Technol. 25 (6), 697-702.

Ibrahim S. A. and Mona E. Eleiwa (2008) Response of Groundnut (Arachis hypogaea L.) plants to foliar feeding with some organic manure extracts under different levels of NPK fertilizers. World J. of Agric. Sci. 4 (2), 140-148.

Marschner, H. (1986) Mineral Nutrition of Higher Plants. Inst. of Plant Nutrition, Univ. of Hohenheirn, F.RG. Academic Press, Jovanvich Publisher, London.

Mehta, A.K. and Ram Mohan Rao, D.S. (1996) Effect of Rhizobium inoculation nitrogen and phosphorus application on yield attributes of groundnut. Legume Res. 19(3), 151-154

Mirvat E. Gobarah, Magda, H. Mohamed and Tawfik, M.M. (2006) Effect of phosphorus fertilizer and foliar spraying with zinc on growth, yield and quality of groundnut under reclaimed sandy soils. J. of Applied Sci. Research, 2(8), 491-496.

Mohamed, A. G. and Usman, A. R. A. (2007) Impact of drip irrigation management on peanut cultivated in sandy calcareous soil. Assiut. J. Agric. Sci. , 38(2),191-206.

Nasr-Alla, A.E., Osman, Fatma A.A. and Soliman, K.G. (1998) Effect of increased phosphorus and potassium or sulfur application in their different combinations on yield, yield components and chemical composition of Peanut in a newly reclaimed sand soil. Zagazig J. Agric. Res., 25, 557-579.

Patel, M.P., Shelke, V.B. and Shelke, D.K. (1990) Response of groundnut to weed management and phosphate in premonsoon season. J. Maharashtra Agric. Univ. 15, 313-316.

Plaut, Z. and Ben-Hur, M. (2005) Irrigation management of peanut with a moving sprinkler system: runoff, yield and water use efficiency. Agronomy J. 97, 1202- 1209.

Sanker, A.S., Reddy, P.R. and Rao, I.V.S. (1984) Nodulation and nitrogen fixation in groundnut as affected by seed size and phosphorus. Legume Res., 7,1-5.

Savani, Y.N., Vaioshnav, M.R., Vaishnavand, P.R. and Darji, V.B. (1995) Statistical estimation of relatives changes in $\mathrm{P}$ content with different levels of applied phosphorus in groundnut. Gujarat Agric. Univ., 21, 119-123.

Sharma, B.M. and Yadav. J.S.P. (1997) Availability of phosphorus to grain as influenced by phosphatic fertilization and irrigation regimes. Indian J. Agric. Sci. 46, 205-210. 
Singh, A. L. and Chaudhari, V. (1996) Interaction of sulphur with phosphorus and potassium in groundnut nutrition in calcareous soil. Indian J. Plant Physiol. New Series (1), 21-27.

Smith, N. (1991) CROPWAT model for ETo calculation using penman monteith method. FAO.

Steel, R.G.D. and Torrie, J.H. (1982) Principals and Procedures of Statistics. A Biometrical Approach. Mc Graw Hill Book Company, New York. USA.

Tayel, M. Y. and Wahaba, S. A. (1989) The effect of sprinkler irrigation schedule on the yield of groundnut (Arachis hypogaea) grown in salbea project. Egypt. J. Soil Sci. 29(3), 305-315.

Tayel, M.Y., El-Dardiry, E.I. and Abd El-Hady, M. (2006) Water and fertilizer use efficiency as affected by irrigation methods. American-Eurasian J. Agric. \& Environ. Sci., 1 (3) 294-301.

Tayel, M.Y., Shaaban, S.M., Ebtisam, I. El-Dardiry and Sabreen, Kh. (2010) Effect of injector types, irrigation and nitrogen levels on II- Garlic yield, water and nitrogen use efficiency. Journal of American Science, 6 (11), 38-46.

Tran Thi Thu Ha (2003) Effect of phosphorus fertilizer on groundnut yield in poor alluvial and sandy soils of Thua Thien Hue. Better Crops International, 17 (2), 16-17.

(Received 13/11/2012; accepted 20/9/2015)

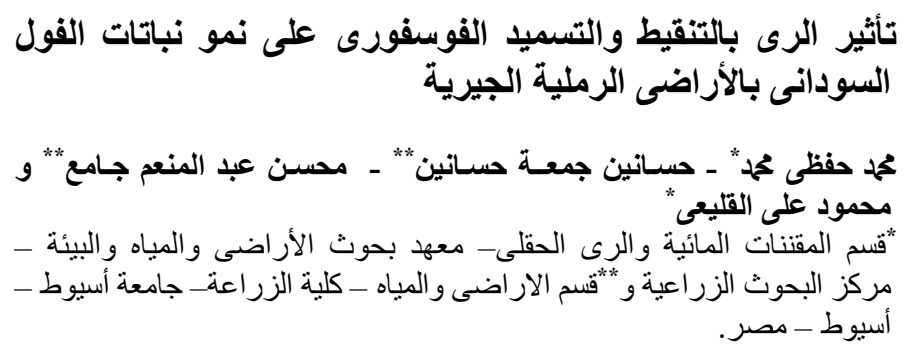

أجريت تجربة حقلية بالمزرعة التجريبية لمحطة بحوث عرب العوامر بأسيوط /

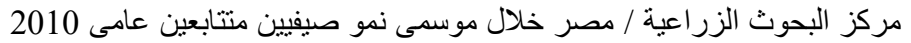

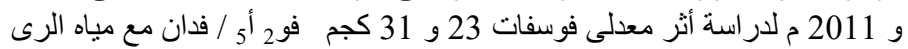

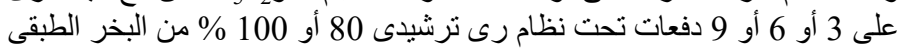

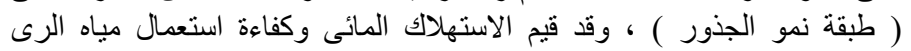

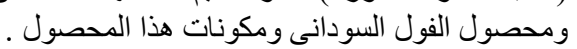

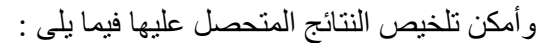

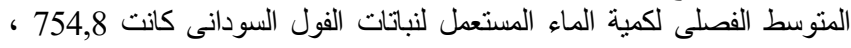

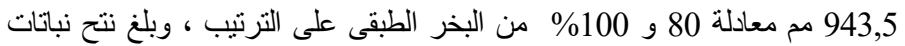

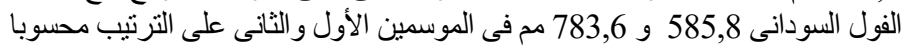

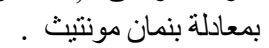

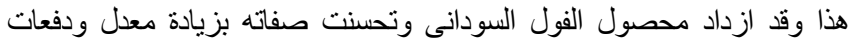

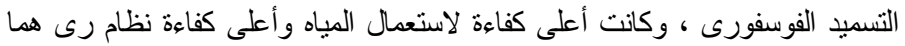

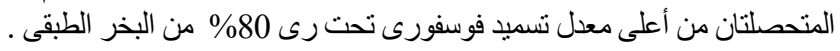

Egypt. J. Soil Sci. 55, No. 1 (2015) 